\title{
Creative Aspiration and the Betrayal of Promise? The Experience of New Creative Workers
}

Stephanie Taylor and Susan Luckman

\section{INTRODUCTION}

The attractions of creative work appear to be undiminished, even though its challenges are now well recognised. In many industries, notably the more lucrative, the creative workforce is skewed towards the conventional categories of privilege: it is largely white, middle class and predominantly male (Conor et al. 2015). These disparities have been particularly well researched in the UK (Banks and Milestone 2011; Banks and Oakley 2016; Conor et al. 2015; Eikhof 2017; Eikhof et al. 2018; Eikhof and Warhurst 2013; Friedman et al. 2016; Grugulis and Stoyanova 2012;

S. Taylor $(\bowtie)$

Faculty of Social Sciences, The Open University, Milton Keynes, UK e-mail: stephanie.taylor@open.ac.uk

S. Luckman

UniSA Creative, University of South Australia, Adelaide, SA, Australia e-mail: susan.luckman@unisa.edu.au

(C) The Author(s) 2020

S. Taylor, S. Luckman (eds.), Pathways into Creative

Working Lives, Creative Working Lives, https://doi.org/10.1007/978-3-030-38246-9_1 
Hesmondhalgh and Baker 2015; Oakley and O'Brien 2016; O'Brien et al. 2016; Scharff 2018; Wreyford 2015). However, they are increasingly acknowledged as a more widespread and problematic feature of the cultural and creative landscape (Azmat and Rentschler 2015; Basas 2009; Gregory and Brigden 2017; Morgan and Nelligan 2018; Screen Australia 2016; Smith et al. 2019; North 2012, 2015). Both academics and workers themselves are aware that creative employment is frequently insecure. Furthermore, earnings are limited but working hours are not, making it difficult to reconcile the demands of professional and personal lives. This chapter looks at pathways into creative work and the obstacles that cultural and creative workers (differentially) face as they attempt to achieve security, prosperity and a manageable work-life balance.

The chapter draws on recent research from a number of different countries, including the UK, the USA and Australia. The second section discusses the personal, 'Do It Yourself' (DIY) serendipitous pathways that are strongly associated with 'following your dream' and 'doing what you love'. The third section evaluates higher education as a seemingly more structured way into a creative career. The fourth section summarises some of the issues that nonetheless confront many creative workers, including graduates, as a result of informal work practices, self-employment, geographic location and personal identities. The fifth section outlines the subsequent chapters in the collection; these critically explore creative work pathways as they are experienced by workers in a wide range of national contexts including Australia, Belgium, China, Ireland, Italy, Finland, the Netherlands, Russia and the UK.

\section{Finding Your Own Pathway into Creative Work}

The creative industries are strongly associated with improvised, relatively informal and serendipitous entry pathways in which a personal interest or leisure project is transformed into an income-earning working life. The promise is that a creative talent and personal interest can become the entry point into a creative career. Workers search for 'new employment spaces where pleasure, autonomy and income seemingly coexist' (Duffy 2016, p. 422).

The general assumption that creativity can be monetised was of course central to the UK's early identification and celebration of the creative industries (Department for Culture, Media and Sport 2001). For the individual worker, an improvised personal pathway is consistent with the 
creative ethos that following your dream or 'passion' is a formula for achieving eventual success (Banks 2007; Luckman et al. 2019a). Taylor and Littleton (2012) found that aspiring workers in a range of creative fields recount stories of a childhood enthusiasm and talent for things creative, presenting these early markers of creativity as both a warrant and qualification for an eventual career. Likewise, the designer makers studied by Luckman and Andrew (2020) frequently trace back their commitment to making either to formative creative family environments, supportive teachers and pedagogic experiences that celebrated creativity (such as Steiner-inspired school models) or simply to the powerful affective experience of being rewarded for having a talent for making.

In some creative industries, like the performing arts, there is of course a well-recognised pathway from amateur activity to a professional status and possible full-time earning. Biographies of actors and musicians are likely to cite school plays, television talent contests, youth orchestras and drama groups as sites where careers began. As a recent example, Seman (2019) discusses contemporary 'DIY music venues' in the USA that function as 'incubation spaces facilitating arts entrepreneurship' (p. 233), offering volunteers an opportunity to refine necessary skills and develop their careers. The computer games industry is well known for utilising the user-led content of amateur players in the production of new games. An enthusiasm for gaming may even be accepted as a qualification for employment in the industry (Banks 2013; Bruns 2007; Kerr and Kelleher 2015; see also Josefsson 2018). However, researchers note the limitations of these contemporary amateur-to-professional pathways and, particularly, the potential for the enthusiasm of the novice workers to be exploited. Kerr and Kelleher (2015) conclude from their research on the gaming industry that ' $[\mathrm{p}]$ assion has an elevated status in recruitment processes, but its deployment seems to be a very neoliberal call for (complete) emotional commitment to the company' (p. 190). Other researchers have also noted the potential for self-exploitation (Banks 2007; Duberley and Carrigan 2012; Duffy 2017), yet many creative aspirants willingly contribute unpaid aspirational labour in hopes of a final pay-off (Duffy 2016, 2017; Duffy and Hund 2015; Duffy and Pruchniewska 2017).

In the absence of paid employment options, the improvised pathway often involves the selling of creative outputs. The hope is that an artist or maker will be able to live off the sales after gradually building up a reputation or, more dramatically, gaining the 'big break' of recognition (Taylor and Littleton 2012 , p. 68). Social media become the space in which new 
kinds of creatives seek to be 'discovered'. Researching creative makers who sell on the Etsy online market place, Luckman (2015) noted that their promotional profiles usually describe a 'moment of revelation' (p. 101) in which the maker (in the majority of cases, a woman) decides to prioritise the creative practice that she loves over more mundane or oppressive employment. She escapes into freedom and her business then develops in 'a narrative of seemingly "natural" growth' (p. 101). The image of the improvised pathway into a creative career is perpetuated, even though statistics indicate that only a minority of craft makers make enough money to live on from their creative work alone (Luckman and Andrew 2018, p. 32).

A similarly serendipitous image is invoked in media accounts of the new creative occupations of blogging and vlogging. There is a suggestion that 'anyone' can convert their use of social media into a career. However, the actual transition is extremely difficult. Ashton and Patel (2018) found that the few individuals who do successfully professionalise these activities must utilise considerable expertise, and also make substantial investments of money and time. Yet the mythology that 'you can make it too' is persistent and persuasive.

In apparent contrast to these improvised pathways, education and training courses prima facie appear to offer a surer entry point to a creative career. A recent EU-funded project on creative industries and the digital economy (Luckman et al. 2019a) noted the very wide range of available courses. These target different audiences, from young people who are outside other approved pathways (in UK terms, 'not in education, employment or training'-the so-called NEETs) (see also van den Berg, this collection) to mature workers seeking to upskill or retrain. The higher education sector in particular has become closely implicated with the creative economy through the training of graduates, the rebranding and realignment of many arts and humanities degrees as 'creative industries', and also through the contributions of universities to 'the cultural life and offer of many cities' (Gilmore and Comunian 2016, p. 2). The next section discusses higher education as a heavily marketed pathway into creative work and careers.

\section{The Higher Education Pathway}

The introduction and embrace of the discourse of the 'creative industries' since the mid-1990s has had a profound impact on creative higher education, and its marketing (Flew 2019). There has been a new emphasis, 
often described as 'neoliberal', upon the potential of creative degrees to capitalise entrepreneurially upon students' creative interests. The shift has been particularly acute in those countries where governments have embraced and championed the economic promises of creative industries policy. This section looks at recent related research from the UK, Australia and the USA.

In the UK, the creative industries are strongly associated with 'the art school system' (Banks and Oakley 2016). Many art schools were originally established in the nineteenth century to produce a skilled workforce for industry. Their subsequent relationship to work and employment has been more complex. Mark Banks and Kate Oakley (2016) describe how, by the mid-twentieth century, the schools had become 'an indeterminate context for the cultivation of a type - the creative or artistic personality-whose "career path", was regarded as an extrinsic and external matter' (p. 48). Local art schools offered many students who would not previously have entered tertiary education an opportunity to experiment and take up a new identity. For a number of famous names of the past (including John Lennon, Keith Richards, David Bowie and Jarvis Cocker) and a much greater number of unknown aspirants, this turned out to be the identity of a musician.

Curricula later became more regulated as art colleges were linked to universities, but some of the earlier association persists. For example, a 2019 recruitment poster for a well-known London university featured a portrait of a former graduate above the headline 'risk taker, storyteller, mentor, film maker, entrepreneur'. The last word was highlighted. The image and wording together emphasised the personality of this supposedly successful creative, but with a reference to business and money-making ('entrepreneur') that was lacking in the earlier 'type' described by Banks and Oakley (2016). In the recruitment poster there was also an implied pathway of maturation, and perhaps a lengthy one, as if achieving the identity of a risk-taker and entrepreneur will bring the additional status of a wise elder who is listened to ('storyteller') and asked for guidance ('mentor') by those further back in their creative careers. Similarly, recent research on US art schools found that a major function of their programmes is 'the development of an artistic identity' (Fine 2017, p. 1464). The US research also suggested that art school contacts provide the basis of the professional network that will support the artist's later career development. The London recruitment poster echoes this promise of 
combined creative and practical/business benefits for the appropriately branded creative self (Hearn 2008).

Banks and Oakley (2016) argue that in the New Labour period of the late 1990s and early 2000s, UK art schools shifted to 'a more formal "knowledge transfer" model', an increased emphasis on placements and internships, and a greater expectation that universities would 'now simply “train” arts workers' (p. 50), with a corresponding focus on outcomes and employability. A key concept in this transformation has been the linking of creativity to entrepreneurship, as the recruitment poster indicated (see Agusita and Ashton, this collection). Individual drives towards artistic fulfilment and business success are equated, although the creative worker is expected to accept fewer financial rewards, following the enduring imaginary of the artist in the garret (Taylor 2019). The art school experience has therefore shifted 'much more towards the commercial than the artistic' (Banks and Oakley 2016, p. 51). Similarly, Terry Flew (2019) argues that the rebranding of Australian fine arts programmes as 'creative industries' has signalled a shift for students from an inward focus, on the aesthetics and skills associated with the arts, to a focus outwards, to the wider applications of creativity (Flew 2019, p. 169).

These changes in the UK occurred alongside the introduction of high fees for tertiary education. Many creative arts and design graduates will not be able to repay the loans they have taken out as students (Education and Funding Review Panel (UK) 2019, p. 84). The figure of $£ 50,000$ is often cited as a typical UK graduate debt. Research with US arts graduates has found that graduates with large debts (more than US\$50,000) are less likely to sustain creative careers (Frenette and Dowd 2018). The UK debts may therefore cancel out any benefits of curricula that aim to prepare students for future creative work. There have also been criticisms that the new employability focus serves the interests of employers rather than workers, for example, because it normalises 'subordinating attitudes towards work and the self, promoting free labour and individualistic behaviour, which discourages collective practice and solidarity' (Precarious Workers Brigade 2017, p. 6).

However, these issues do not appear to have restricted the proliferation of higher education courses which present themselves as entry points into creative careers. Angela McRobbie (2016) notes how the promise of a career in 'the creative labour market' now attracts 'the children of the middle classes' from around the world to Master's courses in UK universities, and there are similar international flows into other countries, 
including Australia (Flew 2019). Many of the academics who teach these courses are well aware of the contradiction of preparing students to enter the creative sector while simultaneously seeking to expose its problems through critical research. Agusita and Ashton (this collection) discuss a teaching approach that attempts to reconcile the two positions. Luckman (2020) notes the additional issue that cuts to university budgets have prompted the replacement of expensive studio practice with classroom learning. She suggests that, as a result, many Australian universities and art schools that provide creative higher education, especially in craft and design training, are now ironically 'producing more makers with classical arts backgrounds than budding creative micro-entrepreneurs' (Luckman 2020).

Despite these issues, there is evidence that contemporary universities do successfully prepare graduates for creative careers. A large-scale UK survey of 'graduates from practice-based programmes in art, design, craft and media' (Pollard 2013, p. 47) found that in 2008, four to six years after graduating, the majority had found some relevant employment, although it was often short-term and part-time. The graduates were likely to be selfemployed and engaged in multiple activities simultaneously ('portfolio working'), including unpaid work. The research also found that within a few months of entering the labour market, a third of the graduates had rethought their earlier goals and career plans, often deciding to combine their creative practice with teaching. Nevertheless, a substantial proportion of the graduates reported that they were 'satisfied' with the work they were doing, saying that they could be creative (77\%) and had 'substantial autonomy and independence' (66\%) with 'career opportunities open to them' (69\%).

Research into graduate employment destinations in Australia produced similar findings (Bridgstock and Cunningham 2016; Brook 2016a, b). A study of 'more than 900 Australian creative graduates up to 6-years postcourse completion' (Bridgstock and Cunningham 2016, pp. 17-18) found that the participants were employable and 'believed that their creative degrees had been valuable' although, again, portfolio working was common. This research embraced the assumption that a creative degree is an appropriate training for many different forms of work (Taylor and Luckman, this collection, Chap. 15). Bridgstock and Cunningham (2016) found that "more than half of those engaged in "non-creative" work were nonetheless using the creative disciplinary skills acquired during creative degrees'. These workers in 'embedded and creative service roles' had 
greater employment security but, interestingly, reported less satisfaction with their work: it seemed that 'many still aspired to specialist, cultural production/work', even with the insecurity of self-employment.

A very large-scale survey of US creative graduates found parallels with the UK and Australian experiences. Frenette and Dowd (2018) used computational linguistics and statistical methods to analyse the responses of 52,000 graduates with degrees in the 'arts', namely, 'performing arts (e.g. dance, music, theater), visual arts (e.g. cinema, painting, sculpting), literary arts (e.g. fiction, poetry), design (e.g. architecture, fashion, interior design), as well as arts education, arts administration and art history' (p. 3). ${ }^{1}$ This research confirmed the importance of portfolio working: it found that graduates who freelance are more likely to stay in the arts, as are those who are flexible enough to work 'across occupations' ('generalism') (p. 49).

Career prospects do vary according to the graduate's specialism. Bridgstock and Cunningham (2016) reported that Australian graduates in architecture, advertising and publishing were more likely to have obtained full-time employment and 'higher wages' (p. 16). More generally, they found that design and digital graduates earn more than those from the visual and performing arts. Frenette and Dowd (2018) also noted the advantage for US graduates of a degree in architecture or design. However, Oakley (2013) suggests that for UK graduates 'there is no simple coupling of qualification with employment trajectories' (p. 31). She points out that general degrees, like social science, may provide an entry point into a career in the cultural sector, whereas specialist qualifications, for example in acting, are notoriously weak as a guarantee of a career in the desired field (see Allen, this collection). Graduate prospects are also likely to be affected by the status of the higher education institution, especially given the widespread perception that there are now too many graduates competing for the available work in creative arts and design. Graduates of a prestigious UK art college told Taylor and Littleton (2012) that the greatest benefit of their study had perhaps been to have the name of that institution on their curriculum vitae. Banks and Oakley (2016) conclude that

\footnotetext{
${ }^{1}$ These study specialisms correspond to the creative focus of the research by Pollard (2013) and Bridgstock and Cunningham (2016). They also correspond in part to the "creative industries' listed by the UK Department for Culture, Media and Sport in 2001: 'advertising, architecture, the art and antiques market, crafts, design, designer fashion, film and video, interactive leisure software, music, the performing arts, publishing, software and computer services, television and radio'.
} 
'the route to success lies in holding a degree (in any discipline) from an elite university' (p. 52, emphasis added).

The research findings for the UK, Australia and the USA indicate, therefore, that higher education does provide a pathway into creative work, but it is a pathway that is neither straight nor smooth. Although entry may be easier for some graduates than others, varying, for example, with their specialisms and higher education institutions, the research suggests that a degree in the creative arts does not guarantee a conventionally secure job. This is, of course, partly a reflection of more widespread changes in work and employment (e.g. Sennett 1998), but the pathway into creative work seems to be a particularly difficult one. Bridgstock and Cunningham (2016) conclude:

Creative graduates struggle through an extended education to work transition period that can involve multiple entry attempts, unpaid internships, travel to follow the possibility of work, more education and/or training, and reliance on non-career jobs, family or social security for financial support. (p. 12)

Two chapters in the collection focus on this transition period. O'Brien and Kerrigan present research on the study-to-work pathways of Irish media production graduates, and their reflections on the usefulness of their degree courses. Kim Allen discusses the findings of a longitudinal study with young UK women graduates who attempted to forge creative careers, with varying success.

Bridgstock and Cunningham's account of the education-to-work transitions therefore suggests that the pathway for graduates is not dissimilar to that of workers who seek to enter creative work by improvised routes. The two kinds of pathway intersect, revealing the limits of the credentialling conferred by university degrees. This may explain the finding of Pollard (2013) that UK graduates value continuing education, with $72 \%$ of the research sample returning to formal or informal learning (p. 56). Fine (2017) found that in the US context many of the students entering fine arts programmes had already been practising as artists for several years, sometimes with more success than that experienced by their tutors.

Fine's finding also refers to another point, that most art school educators are also practitioners. The creative expertise of staff of course plays a vital pedagogic role, but an additional reason that many creative practitioners engage in teaching work is to supplement inadequate earnings from 
their creative practice, possibly alongside other jobs as part of a portfolio career. Such are the economic realities of the creative sector, which tutors may or may not convey in their teaching as they upskill the next generation of practitioners, readying them to enter the fray of the creative habitus. With the growing emphasis in creative education on selling the dream of a creative career in order to attract students, there is pressure on these educators to ignore potential difficulties while emphasising entrepreneurial outlooks and skillsets. The next section looks in more detail at some of those difficulties and the obstacles that the students are likely to encounter on their pathways into creative work.

\section{Where the Obstacles Arise}

For creative workers themselves the activities and roles that earn them money are often highly specific, with correspondingly specific attendant difficulties. Nevertheless, research has indicated some common areas where obstacles are likely to arise. This section reviews the issues that creative workers encounter in relation to informal and self-employment, location and identity.

\section{Informal Employment Practices}

The creative industries function as a highly informal field in which few jobs are advertised. There are exceptions, for example, in the more traditional 'professions' such as architecture, but the general picture is of informal networks of contacts built on social capital as key to gaining work and employment (Coles and MacNeill 2017; Friedman et al. 2016; O'Brien et al. 2016; Grugulis and Stoyanova 2012; McRobbie 2002). This feature of the creative industries has been analysed mostly for the ways it further entrenches inequality and a lack of diversity within the creative workforce. For example, 'homophily' refers to the tendency for those offering employment to hire people like themselves (Umphress et al. 2007; Koppman 2016; Leung et al. 2015; Wreyford 2015). Informal recruitment and hiring practices therefore tend to replicate the demographic profile of the existing creative insiders, exacerbating the problem noted by Conor et al. (2015) that 'images, representative figures and other depictions ... become a barrier to the recognition of particular categories of people ... perpetuating their exclusion' (p. 14). 
An additional issue is that spaces for informal networking, such as pubs and even strip clubs, can form challenging environments for many people, such as women, as too can the requirements for 'compulsory sociality' (Gregg 2011; Lee 2019) and self-promotion (Scharff 2018; Allen, this collection). However, the effect of all these practices as barriers to entry into creative work seems to be taken almost for granted, as something that 'just is', like the 'unspeakable' inequalities noted by Gill (2014). For example, David Lee (2019) found that in the 'discursive space' of creative hubs, negative experiences 'tend to be seen by creative workers as individualised failings rather than located as structural features of precarious work' (p. 71).

In this context, unpaid work experience opportunities and (also unpaid) internships and other 'real world' work opportunities have become normalised strategies sought out by would-be aspirants to obtain a 'foot in the door', and to better prepare themselves for the realities of a creative career. In the UK in particular, there has been widespread criticism of internships as exploitative (Oakley and O'Brien 2016; Boffey 2016), but they are clearly not experienced in the same way by all people. In North American research, Shade and Jacobson (2015) found that young women seeking creative careers were willing to put up with the well-publicised difficulties of internships, although they were disappointed if they did not then receive the promised career advantages. Frenette and Dowd (2018) found that US alumni who had 'arts-based internships' were ' $112 \%$ more likely to have a career trajectory that involves staying in the arts' (46-47).

\section{Self-Employment}

In any field, people who work freelance or run their own businesses face challenges and additional tasks that conventionally employed workers do not have to deal with. Perhaps the most pressing and significant is limited earnings. For example, a recent UK government report (Office for National Statistics 2018) found that the modal (most common) income category for the self-employed was around $£ 240$ a week, whereas the equivalent figure for employees was $£ 400$. However, again, this seems to have become taken for granted by most would-be creative workers.

Self-employed workers must also manage risk. On one level, there is exposure to all the fluctuations and uncertainties of the larger economy, probably without the buffer of substantial financial reserves or, in most instances, a strong social welfare safety net. There is pressure to accept 
whatever work is available, without the longer-term planning that might be possible in an organisation that can spread contracted work across a number of employees. On another level, self-employed workers lack the layer of personal protection conventionally provided by an organisation or other employer, including the provision of sick pay, holiday pay and paid parental leave. Some agency workers might receive benefits like holiday pay but, in most cases, the freelancer or small business owner will never have paid time off work. Most self-employed workers are also outside the protection of trade unions, although there is some evidence that alternative forms of collective organisation are arising (Murgia and de Heusch, this collection) in order to respond to the challenges of the 'new normal' workforce (Taylor and Luckman 2018).

In addition, self-employment presents practical requirements related, for instance, to the management of information and communications technologies, tax, insurance, pensions/superannuation and business accounts. These are just some of the tasks that would be managed for most employees by someone else. Similarly, self-employed workers must make their own arrangements for marketing and promotion, liaising with customers and arranging deliveries and, on another level, planning for the future, undertaking research and development, and developing possibilities for new work. Frenette and Dowd's (2018) US survey respondents indicated that they would have liked more preparation for 'business', such as 'how to network and promote themselves, how to handle debt and budgets, how to manage the business concerns associated with their particular arts-based work, how to be entrepreneurial, and how to find jobs' (p. 33). A similar wish was indicated in Luckman and Andrew's (2020) study of Australian designer makers, though often with the acknowledgement that such guidance had been offered on the makers' degree courses, but as students they had not seen it as relevant, dismissing it as an interruption to their arts education (see also O'Brien and Kerrigan, this collection). These practical skills therefore tend to be (re-)acquired informally: online, from fellow practitioners, and simply through trial and error.

Time management presents a further challenge for the self-employed. In addition to the business tasks already noted, self-employment almost inevitably involves digital work, which, as Gregg (2011) has discussed, tends to 'bleed' into formerly private time. A particular issue for creative workers is that digital and other non-creative business tasks curtail the open-ended time required for being creative. One strategy that many workers adopt is to do digital work 'after work', for instance, at home in 
the evening when the worker is not able to make noise or mess, or lacks the energy for creative thinking (Luckman and Andrew 2019). There is an additional requirement to maintain a continuous level of innovation. Pratt et al. (2019) note that as a result, creative workers must occupy a 'complex position of balancing autonomy and risk, fulfilment and self-exploitation' (p. 15).

The difficulties of self-employment are likely to feel even greater because the worker is alone. Research has found that many creative workers who start their own businesses do not plan to expand sufficiently to involve or employ others (Luckman 2018). Like a freelancer, the owner of a micro-enterprise therefore lacks an equivalent to the colleague relationships that can sustain conventional employees. Some substitutes have been noted, such as the loose working alliances and networks of freelance designers discussed by Pitts (2018) or the relationships promoted in coworking spaces (Morgan, this volume). The difficulties of solitude may also explain Frenette and Dowd's (2018) finding that US graduates are more likely to stay in their careers if they engage in the kind of 'entrepreneurial activities' that 'create solidarity for (other) arts-based workers' (p. 50), such as teaching or starting organisations to benefit other workers. However, for many self-employed creative workers the requirement to manage risk and responsibility by themselves presents another potential obstacle to be overcome.

All these challenges may explain why some self-employed creative workers step back from their original practice to support or service other people's creative activities. Examples are practitioners who produce small elements for other people to assemble into original jewellery, or the plain tableware that others can decorate. This is a 'side hustle' (Morgan, this collection), or 'shovel working' (a term derived from the often-quoted maxim that the most reliable way to make money in a gold rush is to sell shovels rather than prospect for gold). A contemporary equivalent is the Etsy sellers who offer tools and raw materials for making, not finished goods.

\section{Location}

The would-be creative worker also encounters obstacles, and some possibilities, that derive from location on several levels. The initial identification of the creative industries is strongly associated with Western economies, especially the Anglophone countries that have now become major 
providers of creative education and training. However, the policy rhetoric of the creative industries was subsequently taken up worldwide, with varying foci and purposes (e.g. Keane 2009). The expectations and possibilities attached to creative work have therefore been crossed and inflected with unique additions from particular contexts.

For example, Ana Alacovska (2018) has explored the distinctive experience of creative workers in post-socialist Balkan countries, finding informal labour practices and coping strategies, all of which are deeply embedded in local relational infrastructures' (p. 55). Xin Gu and Justin O'Connor (this collection) argue that for artists and writers in Shanghai, Chinese state priorities produce distinctive creative spaces and prospects for creative autonomy. Also in this collection, Margarita Kuleva discusses the experience of young curators, art managers and visual artists in Moscow and St Petersburg. Her research reveals how these aspiring creative workers must contend with the complex interplay between neoliberal creative entrepreneurialism imported from the West, and forms of bureaucratic organisation that persist from the Soviet period. Elena Trubina (this collection) presents observations of a different Russian context in which local and international creative activities intersect. She describes the employment experience of young Russian graduates who act as creative mediators at the Ural Art Biennial in Ekaterinburg. Other chapters in the collection draw attention to how differences between national contexts shape the pathways of creative workers who move between them. Frederick Harry Pitts discusses young British 'flexpatriates' and self-initiated expatriates who move to the Netherlands, partly because of the attraction of a different workplace culture. George Morgan's account of co-working spaces notes how demand for these alternative working arrangements is linked to an emerging community of 'digital wayfarers', who function as global nomads.

Some contexts do confer clear advantages. The chapters in this collection by Hanna-Mari Ikonen and George Morgan both draw attention to how state-supported childcare systems in Scandinavia can assist creative workers to develop their careers while raising a family. Another obvious advantage derives from location in the global hub cities which are recognised centres of creative industries. As just one example, in the USA, Frenette and Dowd (2018) note the enormous bonus of location for arts graduates in New York. They benefit from the infrastructure and additional opportunities that the city offers, including audiences. 
The conventional solution to being in the wrong place was to get 'on yer bike', but there are many obstacles to mobility. Hub cities like New York, London and Sydney have high living costs so precariously employed creative workers will have particular difficulty affording living or working space (Schwartz and Neff 2019). Setting up in a new location will itself incur extra costs, and there may be extra obstacles to moving, such as family commitments (Luckman et al. 2019b). Workers who do move may find themselves identified positively as newcomers who bring fresh ideas or, more negatively, as foreigners who do not understand the local ways of doing things. Frederick Harry Pitts (this collection) discusses how the young UK workers who move to the Netherlands find their working experience is shaped in large part by their status as newcomers. They are exploited in this new work context because of their lack of local ties, and also their previous experience of different work schedules.

Other issues around location arise in smaller or more peripheral cities. Many have embraced creativity-based initiatives with the hope of boosting and re-imagining the local economy. Policies seek to recalibrate the local context to the perceived needs of the knowledge economy, and to keep or attract 'creative' workers (Florida 2002; Landry 2000; O'Connor 1999; Yeoh 2005). In particular, creative industries policy narratives are often embraced by cities and regions hit hard by the loss of traditional manufacturing jobs to cheaper offshore locations (Coppola and d'Ovidio 2018; Trubina, this collection; van den Berg, this collection). Although such fringe or 'rust-bowl' cities may be able to market their affordability in order to attract artists to start-ups, the aspirations to change the local economy can be challenged by the profile of the existing workforce. Some locations then seek to effectively 'launder' their current populace. This has been almost literally the case in Rotterdam (van den Berg, this collection), where local government initiatives are being set up to offer potential employees access to appropriate clothing, and guidance on how to embody an appropriate new-economy aesthetic. Trubina (this collection) also considers the workforce implications of formerly industrial cities that embrace a cultural and creative industries agenda in order to modernise and rebrand the city. Such initiatives clearly have implications for employment pathways, including in terms of (re)training and the growth of social divides. 


\section{Identities}

The fine line between being seen as desirable 'new blood' and an undesirable 'outsider' is just one example of the obstacles that arise for creative workers at the interface of personal and professional identities. In their research on US arts graduates, Frenette and Dowd (2018) found that 'the odds of women alumni staying in arts-related occupations (after already arriving there) are reduced by $15 \%$ when compared to men alumni, and the odds for people of colour are reduced by $24 \%$ when compared to white alumni' (p. 43). The chapter by Karen Patel (this collection) discusses the effectiveness of a UK 'diversity initiative' that attempted to redress some of these inequalities. Her findings draw attention to the particular challenges attached to social media use which face women makers of colour who are attempting to develop craft careers.

There has been considerable discussion of how family and class advantages operate in the creative industries (e.g. Allen, this collection, Taylor and Luckman, this collection, Chap. 15; see also Friedman et al. 2016; Oakley and O'Brien 2016; O'Brien et al. 2016). Obviously, aspiring creatives will be assisted if their families can subsidise their accommodation and living costs. Shade and Jacobson (2015) found that 'class differences are perpetuated ... as upper-class youth with family support were able to take advantage of intern opportunities' (p. 200). Perhaps less obviously, Frenette and Dowd (2018) found that the kind of 'social capital' associated with middle-class advantage, like family connections to the arts, provides an advantage for arts graduates at the beginning of their careers, but is 'not sufficient for people to stay in the arts long-term' (p. 53).

Gender inequalities in the creative industries have already been alluded to. Too often, the obstacles that women face are reduced to issues of childcare. These do matter profoundly, of course, as Ikonen's research (this collection) indicates. However, a number of researchers have shown the more subtle impacts of gender identities, linked to taken-for-granted expectations about women's and men's capacities and responsibilities. A recent innovative 'big data' analysis (Sleeman 2019) showed that in media accounts of creative workers 'words relating to past creative achievements and leadership activities more frequently referred to men. For example ... "he directed"... "he performed", "he designed", "he managed" and "he founded"'.

Other people's perceptions and expectations of both professional and personal identities therefore become obstacles for would-be creatives. 
Conor et al. (2015) note the requirement 'to construct and enact a particular creative occupational identity, for instance, by conforming to the stereotypes and myths attached to it, including by looking the part' (p. 13). (The self-branding discussed by Gandini and Pais in this collection is an example of identity construction.) The difficulties this can lead to are discussed by Scharff (2018) in her research on women classical musicians. In a profession that is strongly classed, raced and gendered, women-and especially women of colour and those from working-class backgroundsexperience prejudice from other people, which enforces existing inequalities in the profession (see also Allen, this collection; van den Berg, this collection).

In addition, there are obstacles that result from creative workers' own need to reconcile or at least manage the competing expectations associated with different identities (see Ikonen chapter this volume, also Ekinsmyth 2013, 2014). Taylor and Paludan (2019) found that women 'maker-artists' justified their creative practice with reference to its practical utility, apparently avoiding the claim of 'art for art's sake' conventionally associated with the masculine and elite image of the artist. The women musicians in Christina Scharff's research accept self-promotion as a necessity but find it difficult for several reasons (Scharff 2018). They are aware that they must negotiate 'gendered expectations about women's display of confidence' (p. 68), treading 'the fine line between being confident and pushy' (p. 69) in how they will be perceived. Morgan and Nelligan (2015) discuss a similar quandary experienced by young working-class men, for whom the 'branding and performance' required of the creative worker conflict with the image of 'an authentic masculine self, that refuses to perform to the crowd, to strangers and outsiders' (p. 73). Scharff (2018) notes that the women musicians she studied must also subtly manage 'the spectre of prostitution' that attaches to women performing publicly. Finally, there are the deeper issues linked to a gendered subjectivity. A number of writers have suggested that (educated) women are the contemporary (precarious, flexible) workforce's 'ideal entrepreneurial' subjects (Eisenstein 2009; Gill and Scharff 2013) or 'privileged subjects of social change' (McRobbie 2009, p. 15) because they are keen to prove themselves and less likely to complain about the absence of stable full-time employment options and their associated rights and safety nets. 


\section{The Chapters in This Collection}

This chapter has discussed pathways into creative work and the obstacles that aspiring workers are likely to encounter. Previous sections have presented recent research, particularly from the USA, the UK and Australia. There have also been references to chapters from this collection. The final section introduces these chapters in sequence.

The initial chapters focus on transitions and trajectories into creative work. The first two chapters in Part 1 look at pedagogical interventions that aim to provide personal and professional resources for creative graduates. Chapter 2, by Emma Agusita and Daniel Ashton, considers some of the issues raised by 'enterprise education' as part of the higher education pathway into creative work. Although universities present entrepreneurship, including self-promotion and work on the self, as a valued aspect of graduate options and outcomes for students, critical research on the creative industries has challenged this celebration. Agusita and Ashton describe a teaching project with university students and established entrepreneurs that used activities and critical reflections to contest dominant understandings of creative entrepreneurship, potentially presenting students with a fuller and more realistic understanding of the creative work experience they will encounter. The complexity of the transition through higher education is evidenced again by the research presented in Chap. 3 . Anne O'Brien and Kerrigan discuss findings from an interview study with Irish media production graduates. They conclude that graduates need confidence to manage precarity. Their research also highlights a further tension around the higher education pathway in that their participants had conflicting aspirations, on the one hand wanting the status of a degree but on the other regretting that they had not received relatively low-level skills training.

The next four chapters offer empirical research findings that contribute insights into the actual negotiation of transitions and trajectories across a number of geographic contexts. Chapter 4, by Margarita Kuleva, discusses the career trajectories and professional identities of recent creative graduates from Moscow and St Petersburg. Kuleva's research explores a tension related to location that is distinctive to the post-Soviet Russian context, but perhaps exemplifies the breadth of the creative industries. She finds that the graduates she studied operate in a 'hybrid economy' comprising the older national arts establishment, dominated by traditional bureaucratic institutions, and the international contemporary arts sector, which is 
dominated by neoliberal practices. In Chap. 5, Kim Allen adopts a longitudinal research approach, returning to UK women graduates a decade after their studies in order to find out how they have experienced transitions into the creative economy. Some of these young women have abandoned the hope of a creative career, while others persist in their aspirations, but with less optimism. The chapter shows how the transition into creative work is shaped by gender, class and race.

Chapter 6, by Xin Gu and Justin O'Connor, explores the social space available for creative subjects in China, based on interviews with artists and writers in Shanghai. Building on Bourdieu's notion of the creative field, the authors suggest that the state adds a distinct parallel polarity to that of restricted versus commercial production. Outside of both commerce and state-sanctioned art, there is a very precarious space of independent cultural activity. The transition to creative 'autonomy' therefore rests on a sense of 'serving the public good', rather than the free creativity associated in the West with Romanticism.

Chapter 7 , by Elena Trubina, examines another distinctive pathway that emerges from the interplay of local and global contexts. She studies the Ural Industrial Biennial as a context in which local audiences encounter specialised cosmopolitan discourses around the production, distribution and consumption of contemporary art. The chapter examines the experience of volunteers who mediate the encounter by presenting and explaining the Biennial's exhibitions. The volunteers take on this role because they are attracted by the possibility that it will assist an eventual transition into creative employment.

The second section of the collection explores significant concepts and new practices that potentially impact on pathways by reframing the creative worker experience. In Chap. 8, George Morgan looks at co-work spaces in three cities-Sydney, Ho Chi Minh City and Reykjavik. He explores the emergence of co-working both as a discursive category and a concrete social arrangement. He argues that those who set up and convene such spaces do so from a commitment to the ethical principles of collaboration, mentorship and skill-sharing. However, the co-work centres also enable these owners and convenors to diversify their own working lives and supplement their precarious incomes as freelancers, becoming part of the improvised pathway of their creative careers. Chapter 9, by Frederick Harry Pitts, discusses the different pathways offered by expatriation. His research focused on young British flexpatriates and self-initiated expatriates working in the graphic design, branding and advertising sector 
in the Netherlands. The chapter considers how the mobility of people and management practices has given rise to hybrid local-global spaces in which contradictions arise around expectations and working practices.

Chapter 10, by Karen Patel, considers an initiative to address inequalities in the UK craft sector where the workforce is dominated by the white and relatively privileged, as in other parts of the UK creative industries. The initiative sought to provide social media skills training to women makers from black and minority ethnic (BAME) backgrounds in two UK cities, Birmingham and London. The chapter discusses the specific challenges facing women makers of colour who are looking to use social media for the benefit of their craft practice.

The next two chapters explore other progressive interventions that might address some of the challenges of creative work. Chapter 11, by Hanna-Mari Ikonen, refers to a contribution at the level of government policy, Finland's childcare support system. Ikonen discusses the experience of Finnish women who are attempting to balance motherhood and creative entrepreneurship. These 'mumpreneurs' must contend with the insecurities of creative work and also the current culture of intensive mothering, which has made motherhood more challenging than in the past. The chapter suggests that the Finnish childcare system and culture of women's work together impact positively on these women's interpretations of their situations. In Chap. 12, Annalisa Murgia and Sarah de Heusch present an example of the emergence of new modes of solidarity. They discuss the Smart cooperative of 'salaried autonomous workers', which was established in Belgium in the 1990s and is now supporting more than 100,000 workers in different employment sectors across nine European countries. Their research shows how precaritisation and the individualisation of labour can be countered by new forms of collective organisation.

Like Chap. 12, the next two chapters show how now-normalised practices in the creative sector are shared with those in other employment areas. In Chap. 13, Alessandro Gandini and Ivana Pais discuss how personal branding has spread from its traditional white-collar domain to be taken up by a much wider range of workers, including creative workers and low-skilled platform workers. The chapter discusses the signalling logics of personal branding that derive from peer evaluation and are related to self-commodification as a new aspect of everyday life for these workers. Chapter 14, by Marguerite van den Berg, looks at how urban economic government has adopted expectations towards populations that originated in the creative industries. Taking the example of Rotterdam in the 
Netherlands, the chapter looks at initiatives to introduce aesthetic pedagogies and impose aesthetic evaluations on unemployed citizens. The industries are part of projects to improve these people's labour market prospects and to develop the city's prosperity.

In all three of these chapters (Murgia and de Heusch, Gandini and Pais and van den Berg), a key part of the argument is that many practices that are often associated with the creative sector are now part of a new normal for all kinds of labour, especially service industry jobs (see Taylor and Luckman, this collection, Chap. 15). An excess of willing workers and the mainstreaming of social media in our lives contributes to self-exploitation and the collapse of boundaries between life and work, leading to long hours and the normalisation of promotional labour expectations. Forms of worker exploitation within the creative industries are mirrored throughout much of the contemporary workforce. The parallels indicate the need for empirically grounded research into not only the problems of but also the solutions to the challenges of creative work pathways.

The final chapter, by Stephanie Taylor and Susan Luckman, returns to the focus on pathways, comparing classic accounts of entry to working life with those that are implied in contemporary writing on creative work, including the chapters presented in this collection. The chapter offers a critique of the promises implicit in higher education and workplace aspirational discourse, but also notes the agency of creative workers in negotiating the ups and downs of their own employment pathways. The chapter concludes by considering the significance of a worker viewpoint of a creative pathway.

\section{REFERENCES}

Alacovska, A. (2018). Hope labour revisited: Post-socialist creative workers and their methods of hope. In S. Taylor \& S. Luckman (Eds.), The new normal of working lives (pp. 41-64). Cham, Switzerland: Palgrave Macmillan.

Ashton, D., \& Patel, K. (2018). Vlogging careers: Everyday expertise, collaboration and authenticity. In S. Taylor \& S. Luckman (Eds.), The new normal of working lives (pp. 147-170). Cham, Switzerland: Palgrave Macmillan.

Azmat, F., \& Rentschler, R. (2015). Gender and ethnic diversity on boards and corporate responsibility: The case for the arts sector. Journal of Business Ethics, 141(2), 317-336.

Banks, M. (2007). The politics of cultural work. Basingstoke: Palgrave Macmillan. Banks, J. (2013). Co-creating videogames. London: Bloomsbury Academic. 
Banks, M., \& Milestone, K. (2011). Individualization, gender and cultural work. Gender, Work and Organization, 18(1), 73-89.

Banks, M., \& Oakley, K. (2016). The dance goes on forever? Art schools, class and UK higher education. International Journal of Cultural Policy, 22(1), 41-57.

Basas, C. G. (2009). Indulgent employment? Careers in the arts for people with disabilities. Rutgers Law Journal, 40(3), 613-667.

Boffey, D. (2016, 13 November). Social mobility tsar calls for an end to unpaid internships and hits at 'elitist' UK. The Guardian. Retrieved October 25, 2019, from https://www.theguardian.com/society/2016/nov/12/unpaid-internselitist-uk-social-mobility-alan-milburn.

Bridgstock, R., \& Cunningham, S. (2016). Creative labour and graduate outcomes: Implications for higher education and cultural policy. International Journal of Cultural Policy, 22(1), 10-26.

Brook, S. (2016a). The exemplary economy: A Hunterian reading of the creative industries as educative project. International Journal of Cultural Policy, $22,27-40$.

Brook, S. (2016b). The creative turn in Australian higher education. In R. Comunian \& A. Gilmore (Eds.), Higher education and the creative economy (pp. 242-260). London: Routledge.

Bruns, A. (2007). Produsage: Towards a broader framework for user-led content creation. Creativity and cognition: Proceedings of the 6th ACM SIGCHI conference on Creativity \& Cognition, ACM, Washington, DC. Retrieved October 30, 2019, from https://eprints.qut.edu.au/6623/1/6623.pdf.

Coles, A., \& MacNeill, K. (2017). Policy ecologies, gender, work and regulation distance in film and television production. In D. Peetz \& G. Murray (Eds.), Women, labor segmentation and regulation: Varieties of gender gaps (pp. 211-231). New York: Palgrave Macmillan.

Conor, B., Gill, R., \& Taylor, S. (2015). Gender and creative labour. In B. Conor, R. Gill, \& S. Taylor (Eds.), Gender and creative labour (pp. 1-22). Chichester: Wiley Blackwell/The Sociological Review.

Coppola, A., \& d'Ovidio, M. (2018). Embedded economic practices in the city of Taranto: The many capitals of community economies in challenging places. Retrieved January 5, 2020, from https://www.academia.edu/39807031/ Embedded_economic_practices_in_the_city_of_Taranto_The_many_capitals_ of_community_economies_in_challenging_places_2018_.

Department for Culture, Media and Sport. (2001). Creative industries mapping document. London: HMSO.

Duberley, J., \& Carrigan, M. (2012). The career identities of 'mumpreneurs': Women's experiences of combining enterprise and motherhood. International Small Business Journal, 31(6), 629-651.

Duffy, B. E. (2016). The romance of work: Gender and aspirational labour in the digital culture industries. International Journal of Cultural Studies, 19, 441-457. 
Duffy, B. E. (2017). (Not) getting paid to do what you love: Gender, social media, and aspirational work. New Haven, CT: Yale University Press.

Duffy, B., \& Hund, E. (2015). "Having it All" on social media: Entrepreneurial femininity and self-branding among fashion bloggers. Social Media + Society, 1, 1-11.

Duffy, B., \& Pruchniewska, U. (2017). Gender and self-enterprise in the social media age: A digital double bind. Information, Communication \& Society, $20(6), 843-859$.

Education and Funding Review Panel (UK). (2019). Independent panel report to the Review of Post-18 Education and Funding. Assets Publishing Service. Retrieved October 24, 2019, from https://assets.publishing.service.gov.uk/ government/uploads/system/uploads/attachment_data/file/805127/ Review_of_post_18_education_and_funding.pdf.

Eikhof, D. R. (2017). Analysing decisions on diversity and opportunity in the cultural and creative industries: A new framework. Organization, 24(3), 289-307.

Eikhof, D. R., \& Warhurst, C. (2013). The promised land? Why social inequalities are systemic in the creative industries. Employee Relations, 35(5), 495-508.

Eikhof, D. R., Newsinger, J., Luchinskaya, D., \& Aidley, D. (2018). And ... action? Gender, knowledge and inequalities in the UK screen industries. Gender, work and organisation, 26, 840-859.

Eisenstein, H. (2009). Feminism seduced: How global elites use women's labor and ideas to exploit the world. Boulder, CO and London: Paradigm Publishers.

Ekinsmyth, C. (2013). Managing the business of everyday life: The roles of space and place in 'mumpreneurship'. International Journal of Entrepreneurial Behaviour \& Research, 19(5), 525-546.

Ekinsmyth, C. (2014). Mothers' business, work/life and the politics of 'mumpreneurship'. Gender, Place and Culture, 21(10), 1230-1248.

Fine, G. A. (2017). A matter of degree: Negotiating art and commerce in MFA education. American Behavioral Scientist, 61(12), 1463-1486.

Flew, T. (2019). From policy to curriculum: Drivers of the growth in creative industries courses in the UK and Australia. Creative Industries Journal, $12,167-184$.

Florida, R. (2002). The rise of the creative class. New York: Basic Books.

Frenette, A., \& Dowd, T. J. (2018). Who stays \& who leaves? Arts education and the career trajectories of arts alumni in the United States. Retrieved October 26, 2019, from https://www.arts.gov/sites/default/files/Research-ArtWorks-ASU2.pdf.

Friedman, S., O'Brien, D., \& Laurison, D. (2016). Like skydiving without a parachute: How class origin shapes occupational trajectories in British acting. Sociology, 51(5), 1-19.

Gill, R. (2011). Sexism reloaded, or, it's time to get angry again. Feminist Media Studies, 11(1), 61-71. 
Gill, R. (2014). Unspeakable inequalities: Post feminism, entrepreneurial subjectivity, and the repudiation of sexism among cultural workers. Social Politics: International Studies in Gender, State and Society, 21(4), 509-528.

Gill, R., \& Scharff, C. (2013). Introduction. In R. Gill, \& C. Scharff (Eds.), New femininities: Postfeminism, neoliberalism and subjectivity (pp. 1-20). Basingstoke, UK: Palgrave Macmillan.

Gilmore, A., \& Comunian, R. (2016). Beyond the campus: Higher education, cultural policy and the creative economy. International Journal of Cultural Policy, 22(1), 1-9.

Gregg, M. (2011). Work's intimacy. Cambridge: Polity Press.

Gregory, S., \& Brigden, C. (2017). Gendered scenes: Conceptualising the negotiation of paid work and child care among performers in film, television and theatre production. Media International Australia, 163(1), 151-162.

Grugulis, I., \& Stoyanova, D. (2012). Social capital and networks in film and TV: Jobs for the boys? Organization Studies, 33(10), 1311-1331.

Hearn, A. (2008). Meat, mask, burden': Probing the contours of the branded 'self'. Journal of Consumer Culture, 8, 197-217.

Hesmondhalgh, D., \& Baker, S. (2015). Sex, gender and work segregation in the cultural industries. Sociological Review, 63(S1), 23-36.

Josefsson, I. (2018). Affectual demands and the creative worker: Experiencing selves and emotions in the creative organisation. In S. Taylor \& S. Luckman (Eds.), The new normal of working lives (pp. 201-218). Cham, Switzerland: Palgrave Macmillan.

Keane, M. (2009). Creative industries in China: Four perspectives on social transformation. International Journal of Cultural Policy, 15(4), 431-443.

Kerr, A., \& Kelleher, J. D. (2015). The recruitment of passion and community in the service of capital: Community managers in the digital games industry. Critical Studies in Media Communication, 32(3), 177-192.

Koppman, S. (2016). Different like me: Why cultural omnivores get creative jobs. Administrative Science Quarterly, 61(2), 291-331.

Landry, C. (2000). The creative city: A toolkit for urban innovators. London and Sterling, VA: Earthscan.

Lee, D. (2019). Creative hubs, cultural work and affective economies: Exploring 'Unspeakable' experiences for young cultural workers. In R. Gill, A. Pratt, \& T. Virani (Eds.), Creative hubs in question. Dynamics of virtualwork (pp. 69-88). Cham: Palgrave Macmillan.

Leung, W., Gill, R., \& Randle, K. (2015). Getting in, getting on, getting out? Women as career scramblers in the UK film and television industries. In B. Conor, R. Gill, \& S. Taylor (Eds.), Gender and creative labour (pp. 50-65). Chichester: Wiley Blackwell/The Sociological Review.

Luckman, S. (2015). Craft and the creative economy. London and New York: Palgrave Macmillan. 
Luckman, S. (2018). Craft entrepreneurialism and sustainable scale: The persistence and evolution of creative challenges to capitalist growth. Cultural Trends, 27(5), 313-326. https://doi.org/10.1080/09548963.2018.1534574.

Luckman, S. (2020). 'Craftsperson', 'artist', 'designer': Problematising the 'art versus commerce' divide within Australian creative fields today. In D. Stevenson, T. Bennett, F. Myers, \& T. Winikoff (Eds.), The Australian art field: Frictions and futures. New York and Abingdon: Routledge.

Luckman, S., \& Andrew, J. (2018). Online selling and the growth of home-based craft microenterprise: The 'new normal' of women's self-(under)employment. In S. Taylor \& S. Luckman (Eds.), The new normal of working lives: Critical studies in contemporary work and employment (pp. 19-39). Cham, Switzerland: Palgrave Macmillan.

Luckman, S., \& Andrew, J. (2019). Organising the home as making space: Crafting scale, identity, and boundary contestation. In E. Bell, G. Mangia, S. Taylor, \& M. L. Toraldo (Eds.), The organization of craft work: Identities, meanings and materiality (pp. 79-97). London and New York: Routledge.

Luckman, S., \& Andrew, J. (2020). Craftspeople and designer makers in the contemporary creative economy. Cham: Palgrave Macmillan.

Luckman, S., Anderson, H., Sinha, R., Rentschler, R., \& Chalklen, C. (2019a). 'The devil is in the level': Understanding inequality in Australia's Film, TV and Radio industries. Media International Australia. https://doi.org/10.117 7/1329878X19892772.

Luckman, S., Taylor, S., \& Andrew, J. (2019b, April). Creative industries and the digital economy as drivers of EU integration and innovation (CIDEII). Adelaide: School of Creative Industries, University of South Australia. Retrieved from https://www.unisa.edu.au/contentassets/dl3b8086290140a5b22f76d5 6a9e1297/cideii_report_final.pdf.

McRobbie, A. (2002). Clubs to companies: Notes on the decline of political culture in speeded up creative worlds. Cultural Studies, 16(4), 516-553.

McRobbie, A. (2009). The aftermath of feminism. London: Sage.

McRobbie, A. (2016). Be creative. Cambridge: Polity.

Morgan, G., \& Nelligan, P. (2015). Labile labour - gender, flexibility and creative work. In B. Conor, R. Gill, \& S. Taylor (Eds.), Gender and creative labour (pp. 66-83). Chichester: John Wiley \& Sons.

Morgan, G., \& Nelligan, P. (2018). The creativity hoax: Precarious work in and the gig economy. New York: Anthem Press.

North, L. (2012). 'Blokey' newsrooms still a battleground for female journalists. Australian Journalism Review, 34(2), 58-70.

North, L. (2015). Radio: A more equitable platform for female journalists? Australian Journalism Review, 37(2), 159-172.

O'Brien, D., Laurison, D., Miles, A., \& Friedman, S. (2016). Are the creative industries meritocratic? An analysis of the 2014 British Labour Force Survey. Cultural Trends, 25(2), 116-131. 
O’Connor, J. (1999). Popular culture, reflexivity and urban change. In J. Verwijen \& P. Lehtovuori (Eds.), Creative cities: Cultural industries, urban development and the information society (pp. 76-100). Helsinki: University of Art and Design.

Oakley, K. (2013). Making workers: Higher education and the cultural industries workplace. In D. Ashton \& C. Noonan (Eds.), Cultural work and higher education (pp. 25-44). Houndsmills, Basingstoke: Palgrave Macmillan.

Oakley, K., \& O’Brien, D. (2016). Learning to labour unequally: Understanding the relationship between cultural production, cultural consumption and inequality. Social Identities, 22, 471-486.

Office for National Statistics. (2018). Trends in self-employment in the UK. Retrieved October 24, 2019, from https://www.ons.gov.uk/employmentandlabourmarket/peopleinwork/employmentandemployeetypes/articles / trendsinselfemploymentintheuk/2018-02-07.

Pitts, F. H. (2018). Creative labour, before and after 'going freelance': Contextual factors and coalition-building practices. In S. Taylor \& S. Luckman (Eds.), The new normal of working lives (pp. 87-108). Cham, Switzerland: Palgrave Macmillan.

Pollard, E. (2013). Making your way: Empirical evidence from a survey of 3,500 graduates. In D. Ashton \& C. Noonan (Eds.), Cultural work and higher education (pp. 45-66). Houndmills, Basingstoke: Palgrave Macmillan.

Pratt, A., Virani, T., \& Gill, R. (2019). Introduction. In R. Gill, A. Pratt, \& T. Virani (Eds.), Creative hubs in question (pp. 1-28). Cham, Switzerland: Palgrave Macmillan.

Precarious Workers Brigade. (2017). Introduction. Training for exploitation? Politicising employability and reclaiming education. Journal of Aesthetics \& Protest Press. Retrieved from www.precariousworkersbrigade.tumblr.com.

Scharff, C. (2018). Gender, subjectivity and cultural work: The classical music profession. Oxford and New York: Routledge.

Schwartz, B., \& Neff, G. (2019). The gendered affordances of Craigslist 'new-intown girls wanted' ads. New Media \& Society, 21, 2404-2421.

Screen Australia. (2016). Seeing ourselves: Reflections on diversity in Australian TV drama. Sydney: Screen Australia. Retrieved October 29, 2019, from https:// www.screenaustralia.gov.au/getmedia/157b05b4-255a-47b4bd8b-9f715555fb44/TV-Drama-Diversity.pdf.

Seman, M. (2019). Punk rock entrepreneurship: All-ages DIY music venues and the urban economic landscape. In R. Gill, A. Pratt, \& T. Virani (Eds.), Creative hubs in question (pp. 229-244). Cham, Switzerland: Palgrave Macmillan.

Sennett, R. (1998). The corrosion of character. London and New York: W.W. Norton.

Shade, L. R., \& Jacobson, J. (2015). Hungry for the job: Unpaid internships and the creative industries. In B. Conor, R. Gill, \& S. Taylor (Eds.), Gender and creative labour (pp. 188-205). Chichester: John Wiley \& Sons Ltd.

Sleeman, C. (2019, 28 August). Big data analysis reveals staggering extent of gender inequality in creative industries. The Conversation. Retrieved October 
29, 2019, from https://theconversation.com/big-data-analysis-revealsstaggering-extent-of-gender-inequality-in-creative-industries- 121482 .

Smith, S. L., Choueiti, M., Choi, A., \& Pieper, K. (2019). Inclusion in the director's chair: Gender, race \& age of directors across 1,200 top films from 2007 to 2018. Los Angeles: Annenberg Foundation/USC Annenberg Inclusion Institute.

Taylor, S. (2019). A participant concept of contemporary creativity. Social Psychology Quarterly, 82(4), 453-472.

Taylor, S., \& Littleton, K. (2012). Contemporary identities of creativity and creative work. Surrey: Ashgate Farnham.

Taylor, S., \& Luckman, S. (Eds.). (2018). The new normal of working lives: Critical studies in contemporary work and employment. Dynamics of Virtual Work Series. Cham, Switzerland: Palgrave Macmillan.

Taylor, S., \& Paludan, M. (2019). Transcending utility? The gendered conflicts of a contemporary creative identification. Feminism \& Psychology, 30(1), 63-79.

Umphress, E. E., Smith-Crowe, K., Brief, A. P., Dietz, J., \& Watkins, M. B. (2007). When birds of a feather flock together and when they do not: Status composition, social dominance orientation and organizational attractiveness. Journal of Applied Psychology, 92(2), 396-409.

Wreyford, N. (2015). Birds of a feather: Informal recruitment practices and gendered outcomes for screenwriting work in the UK Film industry. Sociological Review, 63(S1), 84-96.

Yeoh, B. (2005). The global cultural city? Spatial imagineering and politics in the (multi)cultural marketplaces of South-East Asia. Urban Studies, $42(5 / 6), 945-958$.

Open Access This chapter is licensed under the terms of the Creative Commons Attribution 4.0 International License (http://creativecommons.org/licenses/ by $/ 4.0 /$ ), which permits use, sharing, adaptation, distribution and reproduction in any medium or format, as long as you give appropriate credit to the original author(s) and the source, provide a link to the Creative Commons licence and indicate if changes were made.

The images or other third party material in this chapter are included in the chapter's Creative Commons licence, unless indicated otherwise in a credit line to the material. If material is not included in the chapter's Creative Commons licence and your intended use is not permitted by statutory regulation or exceeds the permitted use, you will need to obtain permission directly from the copyright holder.

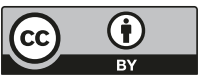

